\title{
Demokracja, rządy prawa i poszanowanie praw czlowieka w aktywności Unii Europejskiej wobec Egiptu ${ }^{1}$
}

Tak zwana Rewolucja 25 stycznia i odsunięcie od władzy H. Mubaraka nie zagwarantowało trwałości zmian i utrwalenia zasad demokratycznych w Egipcie po wydarzeniach tzw. Arabskiej wiosny. $Z$ tego względu, celem Unii Europejskiej i państw członkowskich stało się wzmocnienie stabilności w państwie, promocja wartości demokratycznych i praw człowieka. Celem niniejszego opracowania jest analiza działań skierowanych na wsparcie procesu demokratyzacji w Egipcie, podejmowanych przez Unię Europejską, a także ocena dotychczasowej aktywności i wskazanie przyczyn jej nieskuteczności. Zasadnicza część rozważań poprzedzona zostanie prezentacją genezy zaangażowania Unii Europejskiej w promowanie zasad demokracji, rządów prawa i praw człowieka w państwach trzecich. Scharakteryzowanie kryteriów warunkujących tę aktywność UE jest punktem wyjścia dla ukazania kształtu relacji z Egiptem w omawianym obszarze w okresie poprzedzającym zmiany zapoczątkowane w świecie arabskim w 2011 r. Jest również warunkiem udowodnienia nieskuteczności obecnego zaangażowania organizacji na rzecz demokratyzacji w Egipcie pomimo wielu inicjatyw prawnych i instytucjonalnych.

\section{Geneza aktywności UE na rzecz promowania demokracji, rządów prawa i praw czlowieka}

Jedną z pierwszych inicjatyw odnoszących się do promowania demokracji była debata podjęta podczas spotkania Rady w Kopenhadze w 1978 r. W Deklaracji w sprawie demokracji, przedstawiciele ówczesnych państw członkowskich podkreślili, że jednym z najważniejszych elementów członkostwa we Wspólnotach jest poszanowanie wartości demokratycznych i praw człowieka. Wyrazili poszanowanie dla „uświęconych wartości stanowiących podstawę prawnego, politycznego i moralnego porządku" oraz zobowiązali się przestrzegania zasad „demokracji reprezentatywnej, rządów prawa, sprawiedliwości społecznej i poszanowania praw człowieka" (Declaration, 1978). Idea ta zyskała wymiar formalny w 1986 r., gdy do Jednolitego Aktu Europejskiego wprowadzono wyraźne odniesienia do tych zasad w kontekście współpracy europejskiej. Państwa członkowskie zostały zobowiązane do podejmowania wspólnych działań

1 Niniejszy artykuł jest zmienioną i zaktualizowaną wersją analizy przygotowanej w ramach projektu badawczego pt. Unia Europejska wobec procesów transformacyjnych w Egipcie po 2011 roku. realizowanego na Wydziale Nauk Politycznych i Dziennikarstwa UAM, finansowanego przez Narodowe Centrum Nauki (NN 2012/05/B/HS5/005). 
na rzecz demokracji, opartych na prawach podstawowych wywodzących się $\mathrm{z}$ tradycji konstytucyjnych, Konwencji Rady Europy o ochronie praw człowieka i podstawowych wolności oraz Europejskiej Karty Społecznej. W oświadczeniu wydanym 21 lipca 1986 r. przez ministrów spraw zagranicznych podkreślono, że polityka demokracji i praw człowieka jest jednym $z$ największych wyzwań, a także nieustannym obowiązkiem społeczności międzynarodowej. Zapewniono również o zaangażowaniu na rzecz kontroli przestrzegania tych zasad. Pomimo deklarowanej świadomości na temat potrzeby przyjęcia wspólnej polityki promowania praw człowieka, „odwołanie się do praw podstawowych jedynie w preambule, nie stwarzało jednak żadnych wiążących praw - stanowiło wyłącznie wskazówkę interpretacyjną dla działania organów Wspólnoty" (Wieruszewski, 2008, s. 44).

Przełom w podejściu do idei promowania demokracji w państwach trzecich nastąpił wraz z utworzeniem Unii Europejskiej. Traktat z Maastricht potwierdził zaangażowanie Unii Europejskiej i państw członkowskich w promowanie demokracji oraz rozwoju i ochrony praw człowieka $\mathrm{w}$ działaniach zewnętrznych $\mathrm{w}$ stosunkach $\mathrm{z}$ państwami trzecimi. Już w preambule traktatu zaakcentowano „przywiązanie do zasad wolności, demokracji, poszanowania praw człowieka i podstawowych wolności oraz państwa prawnego" (Traktat, 1992, preambuła). W konsekwencji, uznano że działania UE na arenie międzynarodowej powinny opierać się na zasadach, które zainspirowały jej utworzenie, rozwój i rozszerzenie, tj. na zasadzie demokracji, rządów prawa, uniwersalności oraz niepodzielności praw człowieka i podstawowych wolności, a także na zasadzie poszanowania godności ludzkiej, równości i solidarności oraz na zasadach wyrażonych w Karcie Narodów Zjednoczonych i w prawie międzynarodowym. W traktacie podkreślono, że zaangażowanie Unii Europejskiej w promowanie tych zasad w relacjach zewnętrznych jest kluczowe dla rozwijania tożsamości Unii i państw członkowskich. Zaakcentowano te zasady dwukrotnie, zarówno w Traktacie o Unii Europejskiej, jak i w Traktacie ustanawiającym Wspólnote Europejska. Odnosząc się do współpracy na rzecz rozwoju podkreślono, że: „polityka Wspólnoty [...] przyczynia się do osiagnięcia ogólnego celu rozwoju i wzmocnienia demokracji i zasady państwa prawnego oraz poszanowania praw człowieka i podstawowych wolności" (ibidem, art. 130u.2). Podobnie, wartości demokratyczne zaakcentowano w obszarze wspólnej polityki zagranicznej i bezpieczeństwa. Za jeden z celów tej polityki uznano rozwój i konsolidację demokracji, rządów prawa oraz poszanowanie praw człowieka i podstawowych wolności (Traktat ustanawiający, 1992, art. J.1.2). Realizację założeń i celów wspólnej polityki zagranicznej i bezpieczeństwa oraz współpracy na rzecz rozwoju uzależniono jest od pełnego respektowania przez państwa trzecie praw człowieka i podstawowych wolności, wynikających z międzynarodowego prawa praw człowieka i innych galęzi prawa międzynarodowego.

Uzupełnieniem tych regulacji były wcześniejsze decyzje Rady Europejskiej, podjęte $28-29$ czerwca 1991 r., które określiły wytyczne i priorytety polityki zewnętrznej UE w dziedzinie promowania wartości demokratycznych i ochrony praw człowieka. W deklaracji dotyczącej praw człowieka ustanowiono zasady i główne cechy politycznej platformy promocji praw człowieka i wartości demokratycznych (The European, 1995, s. 6). Takie uregulowania, wzmacniające miejsce demokracji i praw człowieka w systemie prawnym i instytucjonalnym Unii Europejskiej, doprowadzily do stworzenia no- 
wych instrumentów promowania tych wartości z państwami trzecimi. Przedstawiciele Unii Europejskiej zdecydowali o uznaniu poszanowania wartości demokratycznych i praw człowieka za istotny element polityki zewnętrznej, co znalazło wyraz w dwojakiego rodzaju rozwiązaniach. Po pierwsze, idea ochrony i promocji demokracji i praw człowieka została uwzględniona w wieloletnich programach rozwojowych oferowanych przez UE (zgodnie z art. 130w.1, Traktat ustanawiajacy Wspólnotę Europejskq, przyjęty w Maastricht). Po drugie, zobowiązanie do poszanowania tych wartości włączono do porozumień z państwami trzecimi (w oparciu o postanowienia artykułu 130y i 300, Traktat ustanawiający Wspólnotę Europejska, przyjęty w Maastricht), dotyczących współpracy na rzecz rozwoju, ale także do umów stowarzyszeniowych o pomocy technicznej i finansowej oraz do porozumień przedakcesyjnych.

Ustalenia te potwierdzono w kolejnych traktatach reformujących. Wejście w życie traktatu amsterdamskiego wzmocniło rolę UE w promowaniu demokracji i praw człowieka na arenie międzynarodowej. Uwzględniając, że: „Unia opiera się na zasadach wolności, demokracji, poszanowania praw człowieka i podstawowych wolności oraz państwa prawnego" (Traktat, 1997, art. 6.1), realizację tych zasad uznano za podstawę wszelkiej aktywności Unii Europejskiej, również zewnętrznej. Położenie akcentu na fundamentalne znaczenie wolności, demokracji, rządów prawa oraz poszanowania praw człowieka i podstawowych wolności było istotne, zwłaszcza z jednego względu. $\mathrm{O}$ ile w odniesieniu do państw członkowskich, zasady te stanowiły podstawę porządków konstytucyjnych, o tyle w stosunku do państw trzecich Unia Europejska przyjęła na siebie rolę naczelnego promotora idei demokratyzacji, rozpowszechniania i ochrony praw osób indywidualnych. Już we wcześniejszych latach zaangażowanie UE uwidoczniło się w działaniach podejmowanych w państwach byłego Związku Radzieckiego, regionu Bałkanów, w krajach afrykańskich oraz Ameryki Południowej i Środkowej na rzecz budowy społeczeństw obywatelskich, wzmacniania mechanizmów kontroli nad przestrzeganiem praw człowieka, przywracania pokoju i odbudowy po konfliktach, a także walki z rasizmem i nietolerancją, ochrony uchodźców i przesiedleńców, kobiet, dzieci, mniejszości narodowych i ludów autochtonicznych (szerzej: Report, 2000).

Aktywność tę miało zintensyfikować wejście w życie traktatu nicejskiego. Traktat ustanawiajacy Wspólnote Europejskq w wersji zaakceptowanej w Nicei uwydatnił powiązanie polityki zewnętrznej $\mathrm{z}$ dążeniem do rozwoju demokracji i rządów prawa oraz poszanowania praw człowieka i podstawowych wolności (Traktat, 2001, art. 181a.1)2. Podkreślit, że cele te muszą być widoczne we wszystkich sferach współpracy z państwami trzecimi - w kooperacji gospodarczej, finansowej i technicznej. W nowych warunkach traktatowych określono w praktyce trzy obszary, w których wzmożeniu miała ulec działalność Unii Europejskiej (The European's, 2001, s. 5). Pierwszy obszar dotyczył wypracowania spójnego i przejrzystego podejścia do idei demokratyzacji i ochrony praw człowieka w ramach Wspólnej polityki zagranicznej i bezpieczeństwa, ale także Przestrzeni wolności, bezpieczeństwa i sprawiedliwości (dotyczącej m.in. kwestii praw imigrantów i azylantów). Obszar drugi objął wzmocnioną aktywność na rzecz

2 Szerzej: P. Eeckhout (2011), EU External Relations Law, Oxford University Press, Oxford-New York. 
promowania praw człowieka przy wykorzystaniu możliwości oferowanych państwom trzecim w postaci wsparcia technicznego i na rzecz rozwoju. Ostatnia sfera odnosiła się do opracowania strategicznego podejścia do idei rozpowszechniania i ochrony praw człowieka, bazującego na pomocowych programach i projektach o charakterze tematycznym i geograficznym.

Tak zarysowane podejście odzwierciedlił również traktat lizboński o Unii Europejskiej, w którym odniesienia do upowszechniania i ochrony praw człowieka w relacjach z państwami trzecimi i organizacjami międzynarodowymi, dotyczą wspólnej polityki zagranicznej i bezpieczeństwa oraz aktywności UE określonej mianem działan zewnętrznych. Ta ostatnia obejmuje wspólną politykę handlową, współpracę z państwami trzecimi (w szczególności, współpracę na rzecz rozwoju, gospodarczą, finansową i techniczna) i pomoc humanitarna. Wszelkie działania Unii podejmowane na arenie międzynarodowej podporządkowane są realizacji zasad, leżących u podstaw utworzenia, rozwoju i rozszerzenia UE, a więc: „demokracji, państwa prawnego, powszechności i niepodzielności praw człowieka i podstawowych wolności, poszanowania godności ludzkiej, zasad równości i solidarności oraz poszanowania zasad Karty Narodów Zjednoczonych oraz prawa międzynarodowego" (Traktat, 2007, art. 21.1). W konsekwencji, wspólne polityki realizowane są w celu umacniania i wspierania tych zasad, a także w celu „utrzymania pokoju, zapobiegania konfliktom i umacniania bezpieczeństwa międzynarodowego" (ibidem, art. 21.2c), co stało się szczególnie istotne podczas wydarzeń Arabskiej wiosny. Zasady te znajdują odzwierciedlenie we wspólnej polityce zagranicznej i bezpieczeństwa (art. 23 Traktatu o Unii Europejskiej), we współpracy UE z państwami trzecimi na rzecz rozwoju (art. 208.1 Traktatu ustanawiajacego Wspólnote Europejska), we współpracy gospodarczej, finansowej i technicznej (art. 212.1 TFUE) i współpracy handlowej (art. 207.1 TFUE).

\section{Zaangażowanie Unii Europejskiej w budowę demokracji i promowanie praw czlowieka w Egipcie do 2011 r.}

Postanowienia traktatowe dotyczące upowszechniania zasad demokratycznych w stosunkach zewnętrznych wzmocnione zostały wcześniejszymi ustaleniami, w których potwierdzono, że: „trwały rozwój łączy się m.in. z dobrymi rządami, prawami człowieka [...]" (Wspólne, 2006, część I 1.7). W stosunku do państw trzecich, które nie wywiązują się z prawno-międzynarodowych zobowiązań dotyczących promowania demokracji, rządów prawa, wolności i praw człowieka, zezwolono na użycie środków o charakterze wspierającym i oddziałującym, by reagować na problemy związane z naruszeniem praw człowieka. Jednocześnie podkreślono, że w żadnym przypadku działania takie nie mogą być traktowane jako interwencja w wewnętrzne sprawy innego państwa, lecz powinny być uznane za część dialogu międzynarodowego (The European, 1995, s. 10).

W rozporządzeniach przyjętych w 1999 r. wskazano że celem UE jest rozwój i konsolidacja idei demokratycznych i praw czlowieka w stosunkach zewnętrznych. Podkreślono wagę ochrony tych wartości, wskazując na rozpowszechnianie i ochronę praw politycznych i obywatelskich, ekonomicznych, społecznych i kulturalnych, a także 
ochronę praw osób narażonych na dyskryminację, wykluczenie społeczne, ubóstwo, ochronę mniejszości, grup etnicznych i ludności autochtonicznej (Council Regulation, 1999, art. 2.1a-d) ${ }^{3}$. Realizację tych celów uzależniono od wsparcia lokalnych, krajowych i międzynarodowych instytucji, organizacji pozarządowych, centrów rehabilitacji dla ofiar tortur i nieludzkiego lub niehumanitarnego traktowania albo karania, od prowadzenia szkoleń i publicznych kampanii z zakresu ochrony praw człowieka, walki z rasizmem i ksenofobią, a także od monitorowania stanu przestrzegania praw czlowieka w państwach trzecich. Za niezbędne uznano opracowanie kryteriów i procedur podejmowania działań zewnętrznych skierowanych na propagowanie zasad demokratycznych, praw człowieka i podstawowych wolności, z uwzględnieniem dotychczasowych rozwiązań.

W konsekwencji uznano, że poszanowanie demokracji, rządów prawa i praw człowieka jest istotnym warunkiem skorzystania przez państwo trzecie z pomocy i wsparcia finansowego i technicznego w ramach programów rozwojowych oferowanych przez Unię Europejską oraz umów o współpracy gospodarczej, handlowej i na rzecz rozwoju.

W latach 1990-1995 z pomocy wspólnotowej, a następnie unijnej korzystały czterdzieści cztery państwa (Report, 1997, s. 6). Wsparcie skierowane było m.in. na rozwój gospodarczy, ale także na wzmocnienie niezależności sądownictwa krajowego, tworzenie społeczeństwa obywatelskiego, promowanie udziału kobiet w polityce, czy rozwój systemów szkolnictwa. Tak duży krąg beneficjentów dawał w założeniu możliwość rozpowszechnienia nie tylko zasad demokratycznych, ale również idei ochrony praw człowieka. W programach $P H A R E^{4}, T_{A C I S}^{5}, O B N O V A^{6}$, zasady poszanowania wartości demokratycznych, rządów prawa i ochrony praw człowieka uznano za kluczowe elementy współpracy. Ustalono, że naruszenie tych zasad przez państwo korzystające z pomocy skutkować będzie zawieszeniem kooperacji i wstrzymaniem wszelkich form pomocy ze strony Unii Europejskiej.

Identyczne rozwiązanie wprowadzono do programu w sprawie finansowych $i$ technicznych środków wsparcia reform gospodarczych i struktur społecznych w ramach MEDA. Program, realizowany na mocy rozporządzenia Rady 1488/96 z 23 lipca 1996 r. umożliwił udzielenie pomocy finansowej i technicznej państwom basenu Morza Śródziemnego, w tym Egiptowi ${ }^{7}$. Istotną częścią programu było poszanowanie zasad demo-

3 Patrz także: Council Regulation (EC) No. 975/1999.

4 Program utworzony w 1989. Beneficjentami byly Polska i Węgry, a od 1990 również Bułgaria. ówczesna Czechosłowacja i Jugosławia, Niemiecka Republika Demokratyczna i Rumunia, zaś od 1991 - Albania, Estonia, Litwa i Łotwa, następnie Słowienia (od 1992), Chorwacja (od 1995) i byla Jugosłowiańska Republika Macedonii oraz Bośnia i Hercegowina od 1996 r.

${ }_{5}$ Uruchomiony w 1991 r. program pomocy dla państw Europy Wschodniej i Azji Centralnej, skierowany na wsparcie procesów demokratyzacji w państwach byłego Związku Radzieckiego i Mongolii.

${ }^{6}$ Utworzony w 1996 r. w celu rekonstrukcji i odbudowy państw po zakończeniu konfliktów bałkańskich, w szczególności na repatriację uchodźców i przesiedleńców, promowanie pojednania narodowego oraz wzmocnienie wspólpracy regionalnej. Adresatami programu były Bośnia i Hercegowina, Chorwacja, Federalna Republika Jugosławii i Była Jugosłowiańska Republika Macedonii.

7 Podobnie jak: Algierii, Cyprowi, Izraelowi, Jordanii, Libanowi, Malcie, Maroko, Autonomii Palestyńskiej, Syrii, Tunezji i Turcji. 
kratycznych, rządów prawa oraz praw człowieka i podstawowych wolności. Naruszenie tych zasad usprawiedliwić miało przyjęcie stosownych środków (Council Regulation, 1996b, art. 3), ze wstrzymaniem pomocy włącznie. Od 1 stycznia 2007 r. miejsce MEDA zają Europejski Instrument Sasiedztwa i Partnerstwa - ENPI, ustanowiony 24 października 2006 r. na mocy rozporządzenia 1638/2006. Zamierzeniem stał się rozwój współpracy na rzecz zrównoważonego rozwoju regionalnego i zagwarantowanie spójnego i kompleksowego charakteru udzielanej przez Unię Europejską pomocy. Choć wśród celów szczegółowych programu dominuje promowanie rozwoju społecznego, zatrudnienia i ochrony socjalnej, ochrony zdrowia, zrównoważonego rozwoju gospodarczego i zarządzania zasobami naturalnymi, ochrony środowiska naturalnego, wzmocnienie systemów edukacji i redukcja ubóstwa, to istotnym komponentem ENPI jest wspieranie działań państw trzecich na rzecz demokratyzacji oraz promowania i ochrony praw człowieka i podstawowych wolności, w tym praw kobiet i dzieci (Rozporzqdzenie, 2006, art. 1.3, 2.2k). W latach 2007-2013 na realizację programu i pomoc sqsiedzkim krajom partnerskim (tj. 10 państwom basenu Morza Śródziemnego, 7 z Europy Wschodniej, w tym Rosji) oraz rozwój współpracy transgranicznej i dobrosąsiedzkiej przeznaczono 11 miliardów 181 milionów euro. 90\% środków w ramach ENPI przeznaczanych jest na działania dwustronne i realizację inicjatyw poszczególnych państw-beneficjentów. Co istotne, wypłata przyznanych środków może zostać wstrzymana decyzją Rady na wniosek Komisji Europejskiej, gdy państwo partnerskie nie przestrzega zasad demokracji, praworządności, praw człowieka i podstawowych wolności (ibidem, art. 1.3, 28.1). Podstawę realizacji ENPI w Egipcie w latach 2007-2010 stanowił program narodowy, określający priorytety współpracy i finansowego zaangażowania Unii Europejskiej. W oparciu o przyjęte ustalenia na reformy w obszarze demokracji, praw człowieka i sprawiedliwości przeznaczono kwotę $40 \mathrm{mln}$ euro. Paradoksalnie, były to środki żenująco niskie jeśli porównać je z $220 \mathrm{mln}$ przeznaczonymi na zwiększenie konkurencyjności i produkcyjności gospodarki oraz $298 \mathrm{mln}$ skierowanymi na osiągnięcie „zrównoważonego rozwoju i lepszego zarządzania zasobami ludzkimi i naturalnymi".

Co warte odnotowania, choć deklarowanym oficjalnie celem Unii Europejskiej było aktywne wsparcie procesów demokratyzacji w Egipcie, to jednak nie objęto tego państwa Europejska Inicjatywa na rzecz Demokracji i Praw Czlowieka-EIDHR. Podstawą programu skierowanego $\mathrm{m}$.in. na promowanie zasad demokracji, rządów prawa i praw człowieka, było uznanie, iż wszelka pomoc powinna być świadczona bezstronnie, bez jakiejkolwiek dyskryminacji ze względu na rasę, narodowość, przynależność etniczna, wyznanie, płeć, wiek czy poglądy polityczne (Council Regulation, 1996a, preambuła). Utworzona w wyniku aktywności Parlamentu Europejskiego w 1994 r., objęła jednak jedynie państwa dotknięte konfliktami lub odbudowujących się po konfliktach ${ }^{8}$. Dopiero funkcjonujący od 1 stycznia 2007 r., na mocy rozporządzenia Rady 1889/2006 Europejski Instrument na rzecz Demokracji i Praw Człowieka, skierowany na promocję i wzmacnianie demokracji, reform demokratycznych oraz praw człowieka

8 Algieria, Bośnia i Hercegowina, Burundi, Demokratyczna Republika Kongo, Kambodża, Kolumbia, Etiopia, Gwatemala, Haiti, Meksyk, Mozambik, Nepal, Pakistan, Rwanda, Federacja Rosyjska, Strefa Gazy, Tunezja, Turcja i Ukraina. 
w państwach trzecich, a także budowę społeczeństw obywatelskich oraz udzielanie pomocy obrońcom naruszeń praw człowieka i ofiarom takich naruszeń, skierowany został do Egiptu. O środki mogły ubiegać się publiczne i prywatne organizacje non-profit, krajowe, regionalne i międzynarodowe organy parlamentarne, organizacje międzynarodowe, a nawet osoby fizyczne.

Wynikające ze wskazanych programów finansowe wsparcie państw trzecich na drodze do rozwoju i demokratyzacji uruchamiano na podstawie dwustronnych umów, wykorzystywanych jako element aktywności na rzecz promowania demokracji, rządów prawa i praw człowieka. Kompetencję do zawierania tego rodzaju porozumień przyznano pierwotnie Wspólnotom Europejskim. Z chwilą utworzenia Unii Europejskiej, uprawnienie to przysługiwało Wspólnocie Europejskiej, która w imieniu państw członkowskich, za pośrednictwem Komisji Europejskiej prowadziła negocjacje i przystępowała do umów międzynarodowych, zatwierdzanych następnie przez Radę. Traktat o Unii Europejskiej (w wersji zaakceptowanej w Lizbonie), w art. 37 zaakcentował prawo tej organizacji do zawierania umów z jednym lub większą liczbą państw. Uprawnienie to zostało sprecyzowane w art. 209 Traktatu o funkcjonowaniu Unii Europejskiej, gdzie wskazano, iż zawieranie porozumień z państwami trzecimi jest możliwe o ile przyczynia się do realizacji celów, o których mowa w art. 21 TUE i art. 208 TFUE (Traktat o funkcjonowaniu, 2007, art. 209), tj. demokracji, państwa prawnego, praw człowieka i podstawowych wolności, poszanowania godności ludzkiej i zasad równości, zasad wskazanych w Karcie Narodów Zjednoczonych oraz zasad prawa międzynarodowego. Chodzi również o sytuację, w której ,zawarcie umowy jest niezbędne do osiagnnięcia, w ramach polityk Unii, jednego z celów, o których mowa w Traktatach, albo gdy zawarcie umowy jest przewidziane w prawnie wiążącym akcie Unii, albo gdy może mieć wpływ na wspólne zasady lub zmienić ich zakres" (ibidem, art. 216.1).

W przypadku Egiptu, podstawą współpracy stała się dwustronna umowa stowarzyszeniowa zawarta w 2004 r., zastępująca porozumienia z 1977 r. między EWG i Egiptem oraz EWWS i Egiptem. Wśród celów umowy wskazano przede wszystkim rozwój współpracy ekonomicznej, w tym „liberalizację handlu towarami, usługami i kapitałem”, a także działania na rzecz „ekonomicznego i społecznego rozwoju Egiptu, [...] konsolidacji pokojowego wspólistnienia oraz ekonomicznej i politycznej stabilności" (Euro-Mediterranean Agreement, 2004, art. 1.2). Co najważniejsze jednak, uzgodniono że stosunki między stronami oraz postanowienia porozumienia będą bazowały na poszanowaniu zasad demokratycznych i podstawowych praw człowieka (ibidem, art. 2). Zasady te uznano za istotny element porozumienia. W ten sposób nawiązano do tzw. modelu butgarskiego ${ }^{9}$, wyrażającego wolę oparcia wzajemnych relacji oraz wewnętrznych i międzynarodowych polityk na zasadach rządów prawa, demokracji i praw człowieka, uznając je za istotny element porozumień. Zrównano rangę działań na rzecz demokracji z aktywnością skierowaną na pokój i bezpieczeństwo. Wszystkie te obszary objęto dialogiem politycznym realizowanym na szczeblu ministerialnym, eksperckim oraz za pomocą kanałów dyplomatycznych. Potwierdzeniem zaangażowania na

9 Nazwa model butgarski nawiązuje do pierwszych porozumień, w których odwolano się do mechanizmu konsultacji w przypadku naruszenia zasad demokratycznych i praw człowieka. Umowy takie zawarto z Rumunią (1 lutego 1993 r.) i Bułgarią (8 marca 1993 r.). 
rzecz promocji zasad demokratycznych i praw człowieka miało być prawo stron do podjęcia właściwych środków, w przypadku naruszenia zobowiązań dotyczących poszanowania zasad demokratycznych i praw człowieka. Co istotne, a zarazem osłabiające rangę tego uprawnienia, zastosowanie właściwych środków musiało być poprzedzone konsultacjami na forum Rady Stowarzyszenia. Jedynie w przypadku poważnego naruszenia istotnego elementu porozumienia „tworzącego środowisko nieprzyjazne konsultacjom lub gdy zwłoka byłaby ze szkodą dla celów porozumienia" mogło dojść do zawieszenia współpracy (ibidem, art. 86.2). Na mocy przyjętego w 2007 r. Planu działania strony zobowiązały się do wspólnych działań na rzecz wzmocnienia demokracji i rządów prawa oraz promowania i ochrony praw człowieka i podstawowych wolności. Aktywność tę poddano kontroli Radzie Stowarzyszenia UE-Egipt.

Takie rozwiązania nawiązywały do ogłoszonego w grudniu 1996 r. wyroku Europejskiego Trybunału Sprawiedliwości w sprawie Portugalia przeciw Radzie. Sędziowie orzekli wówczas, że unijna polityka współpracy na rzecz rozwoju musi uwzględniać zasady demokracji, rządów prawa i praw człowieka, a w konsekwencji wartości te są nadrzędne w stosunku do polityki współpracy na rzecz rozwoju (Judgment, 1996, pkt 24, 25). Sędziowie podkreślili możliwość zawieszenia współpracy z państwem trzecim, które narusza prawa człowieka. Podporządkowanie założeń i celów polityki współpracy na rzecz rozwoju zasadom demokratycznym i prawom człowieka, wymusiło na Unii Europejskiej ich uwzględnianie zarówno w procesie decyzyjnym skierowanym na przyjmowanie nowych rozwiązań o charakterze prawa europejskiego, jak i w procesach negocjacyjnych, zmierzających do wypracowania porozumień z państwami trzecimi.

Odzwierciedleniem tej tendencji miała być również wielostronna inicjatywa PDGHR - Partnerstwo na rzecz rzqdów demokratycznych i praw czlowieka (ang. Partnership on Democratic Governance and Human Rights), przyjęta w grudniu 2007 r. we współpracy z Unią Afrykańską. Jej celem było „stworzenie i wzmocnienie dialogu politycznego skierowanego na kwestię demokracji, rządów i praw człowieka w stosunkach Unia Europejska - Afryka" (Mangala, 2013, s. 73). Ustanowioną w ramach partnerstwa Platformę dialogu skierowano na wypracowanie zasad współpracy na rzecz promowania praw człowieka, w szczególności praw dzieci i zasady równouprawnienia płci, a także na rzecz walki z korupcja, zwiększenia efektywności administracji państwowej i wzmocnienia roli samorządu w krajach afrykańskich. O tym jak trudno było uzgodnić pierwszy plan działania, świadczyć mogą wysiłki podejmowane w latach 2007-2010. „Grupa implementacyjna Unii Europejskiej, kierowana wspólnie przez Niemcy i Portugalię, wskazała dwie zasady odnoszace się do implementacji PDGHR. Pierwszą była, [...] zasada dzielonej odpowiedzialności zarówno w osiaganiu celów, jak i w wypracowywaniu oczekiwanych efektów. Po drugie, [...] PDGHR miało być skonceptualizowane i wcielone w życie zgodnie z ogólnymi zasadami wyrażonymi we Wspólnej strategii $U E-A f r y k a^{10}[\ldots]$. Afrykańska grupa implementacyjna, kierowana przez Egipt, naciskała, aby 'implementacja i zarządzanie Partnerstwem następowały zgodnie z zasadami: wzajemnego poszanowania i zrozumienia, poszanowania

10 Ang. Joint Africa-EU Strategy. 
tożsamości państw i narodowych priorytetów'. Podkreślała również potrzebę uwzględnienia 'różnych kontekstów społecznych, ekonomicznych, politycznych i kulturowych, w jakich funkcjonują oba kontynenty' [...]" (ibidem, s. 80). Takie podejście w praktyce dawało państwom afrykańskim nieograniczoną możliwość unikania wypełniania zobowiązania do promowania demokracji i praw człowieka, zgodnie z głoszoną przez te państwa tezą o braku uniwersalizmu praw człowieka i potrzebą dostosowania ich rozumienia do warunków regionalnych/lokalnych. Dążenie do wypracowania wspólnego stanowiska zaważyło na ustępstwach ze strony Unii Europejskiej. Efektem spotkania przedstawicieli stron w Addis Abebie we wrześniu 2010 r., skierowanego na analizę stanowisk stron i wypracowanie konsensusu, było przyjęcie tzw. acquis $z$ Addis - zbioru zasad będących podstawą funkcjonowania Partnerstwa. Uzgodniono co prawda, że kluczową rolę w realizacji celów Partnerstwa odgrywać będą państwa Unii Europejskiej i Unii Afrykańskiej, organy obu organizacji, instytucje państwowe krajów uczestniczących i organizacje pozarządowe. W rzeczywistości jednak udział tych ostatnich ograniczono do prezentacji stanowisk w ramach konsultacji. To zaś nakazywało wątpić w możliwość realizacji pierwszego obszaru Partnerstwa obejmującego prawa człowieka i rządy prawa.

Promowanie demokracji, rządów prawa i praw człowieka było także przedmiotem wspólnego zainteresowania Unii Europejskiej i Ligi Państw Arabskich. W lutym 2008 r. zorganizowano pierwsze spotkanie ministrów spraw zagranicznych państw członkowskich obu organizacji, nawiązujące do tzw. inicjatywy maltańskiej z 2006 r. W komunikacie kończącym spotkanie podkreślono wagę reform politycznych i gospodarczych w państwach regionu, gwarantujących stabilność i zrównoważony rozwój. Opowiedziano się za wzmocnieniem współpracy obu organizacji i ich państw członkowskich, przy wykorzystaniu istniejących mechanizmów m.in. Partnerstwa Eurośródziemnomorskiego, Partnerstwa Unia Europejska - Afryka oraz Europejskiej Polityki Sasiedztwa. Określając obszary wspólnego zainteresowania, wyraźnie wskazano na wolę poszanowania zasad demokratycznych, praw człowieka i podstawowych wolności (Malta Communiqué, 2008, pkt 4). Co warte zauważenia, definiując wyzwania i problemy widoczne we wzajemnych relacjach, wskazano na konflikt izraelsko-palestyński, wyrażono zaniepokojenie ówczesną sytuacją w Strefie Gazy, Libanie, podkreślono konieczność monitorowania sytuacji w Iraku, podkreślono zaangażowanie $\mathrm{w}$ walkę $\mathrm{z}$ terroryzmem. Nie wspomniano o naruszeniach praw człowieka, do których dochodziło nagminnie w państwach Afryki północnej, w tym w Egipcie.

\section{Wsparcie procesu demokratyzacji w Egipcie po Arabskiej wiośnie}

Wydarzenia z początku 2011 r. pokazały jak nieskuteczna była polityka Unii Europejskiej skierowana na promowanie wartości demokratycznych, rządów prawa i na ochronę praw człowieka w Egipcie i innych państwach regionu. Lub pokazały raczej, że polityki takiej w praktyce nie było. Pomimo formalnego istnienia mechanizmów kontrolnych, przyznających UE możliwość wywierania skutecznego - w zamyśle - nacisku na rządy państw trzecich, a tym samym wymuszanie pożądanych działań, stale dochodziło do naruszania reguł demokracji i łamania podstawowych praw i wolności 
jednostki przy milczącej akceptacji Unii. Choć oficjalnie Europejska Polityka Sasiedztwa przyznawała „,pierwsze miejsce promocji demokracji, praw człowieka, rządów prawa i rozwojowi społeczeństwa obywatelskiego", instytucje europejskie często nie reagowały na doniesienia o naruszeniach tych zasad w państwach Afryki północnej (Emerson et al., 2007, s. 15). Działo się tak z dwóch powodów. Po pierwsze, naciski UE na przestrzeganie zasad demokratycznych i praw człowieka ustępowały miejsca obawie przed możliwą destabilizacją sytuacji w regionie, gdy w wyniku procesów demokratycznych do władzy doszłyby radykalne ugrupowania islamistyczne (Kausch, Youngs, 2009; Cassarino, Tocci, 2012). Działano więc według formuly stabilizacja ponad demokracje (ang. stability over democracy), postrzegając istniejący reżim jako element stabilizujący. Po drugie, decydujące znaczenie w unikaniu rzeczywistego zaangażowania w promowanie demokracji i praw człowieka w państwach Afryki północnej miały partykularne interesy państw członkowskich UE. Zyski z wymiany handlowej, dążenie do minimalizowania zagrożenia terrorystycznego oraz chęć powstrzymania nielegalnej imigracji skutkowały zgodą na niedemokratyczne działania władz w państwach Afryki północnej. Równie istotne były kontrakty wojskowe - w 2010 r. wartość licencji na sprzedaż broni do Egiptu, Libii i Tunezji wyniosła 531 mln euro (Archick, Mix, 2013, s. 6).

Zmiany do jakich doszło w Egipcie i postęująca destabilizacja wymusiły na Unii Europejskiej i państwach członkowskich rewizję zasad dotychczasowego podejścia (niedemokratyczne reżimy nie zagwarantowały stabilności w państwach regionu) i zwiększenie zaangażowania (jeśli organizacja miała być wiarygodna na arenie międzynarodowej - szczególnie w kontekście otrzymania niecały rok później Pokojowej Nagrody Nobla „za ponad sześć dekad działań na rzecz wzmacniania pokoju i pojednania, demokracji i praw człowieka w Europie" (The Nobel, 2012) - musiała opowiedzieć się za zmianami i faktycznie promować idee demokratyczne oraz prawa i wolności jednostki).

Jedna z pierwszych reakcji na wydarzenia w Egipcie było podjęcie decyzji o sankcjach inteligentnych wobec przedstawicieli egipskich władz. 21 marca 2011 r. na mocy rozporządzenia Rady 270/2011 zdecydowano o zamrożeniu środków finansowych 19 osób, w tym Hosniego Mubaraka, jego żony, dwóch synów i synowych, a także byłego ministra spraw wewnętrznych i byłego ministra handlu i gospodarki (Rozporzqdzenie, 2011, Aneks). Co istotne, oficjalnym powodem takich działań nie były jednak oskarżenia o naruszanie zasad demokracji i praw człowieka $-\mathrm{m}$.in. o siłowe thumienie protestów ze stycznia $2011 \mathrm{r}$, lecz podejrzenia o sprzeniewierzenie funduszy państwowych.

8 marca 2011 r. Komisja Europejska ogłosiła komunikat Partnerstwo na rzecz demokracji $i$ wspólnego dobrobytu z pohudniowym regionem Morza Śródziemnego. Co oczywiste, w dokumencie nie pojawiły się wzmianki na temat nieudanej, dotychczasowej polityki Unii Europejskiej, skierowanej na promowanie wartości demokratycznych w państwach Afryki północnej. W zamian, w komunikacie podkreślono sukcesy UE na tym polu i skuteczne wsparcie przemian w państwach południowej, środkowej i wschodniej Europy oraz chęć realizacji celu, za jaki uznano „demokrację, stabilizacje, dobrobyt i pokój" w południowym regionie Morza Śródziemnego (Wspólny, 2011a, s. 2). Wyrażono oczekiwanie, że wydarzenia Arabskiej wiosny będą skutkowały poszanowaniem zasad „,udziału politycznego, godności, wolności” oraz zaangażowaniem na rzecz „demokracji, praw człowieka, sprawiedliwości społecznej, dobrych rządów i pra- 
worządności" (ibidem). Z tego względu za główny cel Partnerstwa na rzecz demokracji $i$ wspólnego dobrobytu, tworzonego we współpracy z nowymi władzami państw Afryki pólnocnej, uznano „demokratyczną transformację i budowę instytucji, ze szczególnym uwzględnieniem podstawowych wolności, reform konstytucyjnych, reformy sądownictwa i walki z korupcja" (ibidem, s. 3). Jednocześnie jednak już we wstępie komunikatu uwagę zwraca tzw. podejście zróżnicowane. Z jednej strony, uwzględnienie specyfiki poszczególnych państw daje szansę na zwiększenie skuteczności zabiegów podejmowanych przez UE. Z drugiej jednak strony, pozwala na odstępstwa od formalnie promowanych zasad, zgodnie z koncepcja, iż zachodnich wzorców demokracji nie można „przeszczepié" na grunt odmiennych historycznie, kulturowo czy cywilizacyjnie państw. To zaś, jak pokazuje praktyka stosunków międzynarodowych i dotychczasowej działalności UE, skutkuje relatywizacją głoszonych oficjalnie wartości, zasad i regul.

Bezpośrednią konsekwencją Partnerstwa na rzecz demokracji i wspólnego dobrobytu stała się konieczność zrewidowania Europejskiej Polityki Sasiedztwa i jej dostosowania do nowej sytuacji międzynarodowej. Dotychczasowe relacje Unii Europejskiej z państwami Afryki północnej bazowały na tzw. warunkowości. Zgodnie z tym podejściem, warunkiem uzyskania unijnej pomocy była akceptacja i implementacja zasad demokratycznych i praw człowieka. W teorii integracji europejskiej, warunkowość to proces jednostronny, w którym występuje asymetria siby, a który „łączy spodziewane korzyści innego państwa (takie jak pomoc, koncesje handlowe, porozumienia o współpracy, kontakty natury politycznej lub członkostwo w organizacji międzynarodowej) z wypełnieniem warunków odnoszących się do ochrony praw człowieka i wzmacniania zasad demokratycznych" (Balfour, 2012, s. 15). Warunkowość może również przejawiać się $\mathrm{w}$,nakładaniu lub grożeniu nałożeniem sankcji [...] w celu promowania i ochrony demokracji” (Schmitter, Brouwer, 1999, s. 15). W praktyce jednak polityka warunkowości Unii Europejskiej nie przyniosła pożądanych efektów - nie była jednostronna, lecz kształtowana pod wpływem okoliczności politycznych, uwarunkowań gospodarczych i interesów nie tylko państw zabiegających o wsparcie, lecz również państw członkowskich.

W konsekwencji, nowym pomysłem jest podejście motywujace nazwane more for more. Państwa, które wprowadzą reformy i podążą drogą głębokiej demokracji mogą liczyć na zwiększoną pomoc ze strony Unii Europejskiej. Pomoc będzie świadczona w oparciu o uzgodnione przez strony plany reform. Reformy zaś powinny przejawiać się w „odpowiednio monitorowanych, wolnych i uczciwych wyborach”, wzmocnionym dialogu politycznym oraz uwzględnieniu praw człowieka (Wspólny, 2011, s. 5). Nowe podejście wobec państw Afryki północnej doprecyzowano w drugim komunikacie Nowa odpowiedź na zmieniajace się squsiedztwo, przedstawionym 25 maja $2011 \mathrm{r}$. Komisja Europejska opowiedziała się za wzmocnieniem partnerstwa z sąsiednimi państwami i społeczeństwami, w szczególności, aby „budować i konsolidować zdrowe demokracje" (Joint, 2011, s. 1). W dokumencie otwarcie przyznano się nie tyle do porażki, co do ograniczonych rezultatów dotychczasowej pomocy UE na rzecz reform politycznych. $Z$ tego względu, wyrażając wolę rzeczywistego wsparcia procesu reform w państwach regionu Morza Śródziemnego, podjęto zobowiązanie do promowania „uniwersalnych wartości praw człowieka, demokracji i rządów prawa” (ibidem, s. 2). 
Zgodnie z podejściem more for more kooperację Unii Europejskiej z państwami Afryki północnej uzależniono od postępu tych ostatnich w budowie demokracji i rządów prawa. Chodzi zwłaszcza o realizację praw fundamentalnych, obywatelskich i politycznych, takich jak wolność słowa, stowarzyszania się, zakładania partii politycznych, prawo do uczestniczenia w wolnych wyborach, prawo do bezstronnego osądu przez niezależnych sędziów, a także o skuteczną realizację zadań państwa, takich jak walka z korupcją, demokratyczna kontrola nad armią i siłami bezpieczeństwa. W zamian, państwa Afryki północnej mogą liczyć na trojakiego rodzaju wsparcie, tj. na zwiększoną pomoc finansową (money); otwarcie dostępu do europejskiego rynku zbytu (markets); oraz wsparcie na rzecz mobilności (mobility). W praktyce, pogłębioną kooperację zapewnić ma:

- przyjęcie nowych planów działania, określających zasady współpracy z poszczególnymi sąsiadami z Afryki północnej i krótko- oraz długookresowe cele współpracy;

- utworzenie programów budowania instytucji (ang. Comprehensive programmes), wzorowanych na podobnych programach realizowanych ze wschodnimi partnerami UE, zapewniających wsparcie eksperckie i finansowe na rzecz tworzenia sprawnych organów administracji państwowej, w szczególności organów sprawiedliwości i celnych;

- zawieranie porozumień DCFTA (ang. Deep and Comprehensive Free Trade Agreements), których celem jest zwiększenie możliwości wejścia towarów z państw trzecich na rynek europejski, jak i wsparcie reform gospodarczych w tych państwach;

- ustanawianie partnerstw na rzecz mobilności, skierowanych na wspólne zarządzanie ruchami migracyjnymi;

- odnowienie zasad działania Unii dla Śródziemnomorza i finansowanie projektów skierowanych na rozwój gospodarczy, innowacyjność i tworzenie nowych miejsc pracy (w ramach projektu Med $4 J o b s$ ).

W przypadku Egiptu, realizacja wskazanych wyżej założeń odbywa się w ramach tzw. Task Force. Pierwsze spotkanie z udziałem około 500 przedstawicieli Unii Europejskiej, władz Egiptu oraz reprezentantów biznesu i organizacji pozarządowych, odbyło się 14 listopada 2012 r. w Kairze. Choć w dokumencie zawierającym konkluzje ze spotkania potwierdzono, że strony podzielają te same cele i wartości (sprawiedliwość społeczna, rozwój społeczno-ekonomiczny, rządy prawa, prawa człowieka, włączając prawa kobiet i równość płci), to uwagę zwraca sformułowanie o równości partnerów. $\mathrm{W}$ praktyce nie ma więc mowy o realizacji nowego podejścia more for more, gdyż UE nie może działać z pozycji siły i stawiać warunków równemu partnerowi. Może jedynie zabiegać - co podkreślono w dokumencie - o realizację Europejskiej Polityki Sasiedztwa na rzecz budowania „głębokiej i zrównoważonej demokracji” (EU-Egypt, 2012, s. 2). Czyni to angażując środki finansowe. W ramach Europejskiego Instrumentu Sasiedztwa i Partnerstwa, w latach 2011-2013 na realizację założeń przewidziano kwotę ponad 1 miliarda euro, z której realizacji poddano programy na kwotę 892 milionów euro (EU-Egypt, 2013). Środki te przekazano trzy priorytety współpracy i finansowego zaangażowania Unii Europejskiej: wsparcie reform politycznych, praw człowieka i wymiaru sprawiedliwości, reformy gospodarcze oraz zrównoważony rozwój. Dodatkowo, na mocy ustaleń w ramach Task Force, UE zobowiązała się do przekazania dodatkowego wsparcia w wysokości 303 milionów euro w postaci grantów na realizację 
projektów oraz 450 milionów euro w ramach porozumienia z Międzynarodowym Funduszem Walutowym w formie pożyczek i grantów (ibidem).

W chwili przyjmowania konkluzji Task Force w 2012 r. wydawało się, że Egipt podąży drogą demokracji - opracowano projekt nowej konstytucji, przygotowywano się do wyborów, lecz późniejsze wydarzenia pokazały jak złudne były to nadzieje. Przejęcie władzy przez wojsko w 2013 r. zapoczątkowało nową falę represji przeciw zwolennikom obalonego prezydenta M. Mursiego i zejście z drogi ku stabilizacji, demokracji, rządom prawa i prawom człowieka. Nowe rozwiązania prawne ograniczyły wolność słowa i zgromadzen ${ }^{11}$, prowadząc $m$.in. do zamknięcia czterech kanałów telewizyjnych we wrześniu $2013 \mathrm{r}$. w zwiazzu z ,rozpowszechnianiem nieprawdziwych informacji, które zagrażały bezpieczeństwu państwa [...] i porządkowi publicznemu", a w grudniu do zamrożenia środków 1055 organizacji charytatywnych powiązanych z Bractwem muzulmańskim (Egypt: Roadmap, 2014, s. 21, 24). Od momentu przejęcia władzy przez armię, śmierć na skutek użycia siły przez służby bezpieczeństwa poniosło około 1400 osób, zatrzymano od 16 do 40 tysięcy aktywistów - członków zdelegalizowanego $B M$ oraz studentów uczestniczących w ulicznych protestach (Egypt. Human Rights, 2014, s. 6-7).

Niedemokratyczny styl rządów nowych władz spowodował, że nie doszło do wypracowania nowego Planu działania. $\mathrm{Z}$ tego samego powodu rozpoczęte w czerwcu 2013 r. negocjacje UE-Egipt w sprawie porozumienia DCFTA stanęły w martwym punkcie. W założeniu porozumienie ma wykraczać poza ramy umowy stowarzyszeniowej z 2001 r. i regulować także kwestie usług, konkurencji, ochrony własności intelektualnej oraz ochrony inwestycji, dając podstawy tworzenia w Egipcie gospodarki wolnorynkowej. Nie odnotowano również żadnej aktywności na rzecz ustanowienia partnerstw na rzecz mobilności z uwagi na dwukrotną odmowę rozpoczęcia rozmów przez władze Egiptu.

Dopiero nasilający się konflikt w Syrii i kryzys migracyjny, który uwidocznił się szczególnie w 2014 i 2015 r. spowodowały, że współpracę gospodarczą z Egiptem UE uznała za sposób na stabilizację i demokratyzację, a co za tym idzie - na wyeliminowanie potencjalnych zagrożeń dla UE. Na początku grudnia 2015 r. Europejski Bank Inwestycyjny zawarł porozumienie przewidujące pożyczkę $600 \mathrm{mln}$ euro na zabezpieczenie dostaw energii w Egipcie (tj. budowę elektrowni wodnej w delcie Nilu). W grudniu 2015 r. doszło również do podpisania dwóch porozumień zakładających finansowe zaangażowanie Unii Europejskiej na rzecz zwiększenia dostępu do edukacji i ochrony dzieci (pierwsza umowa) oraz na rzecz uruchomienia programu oczyszczania wody pitnej w regionie Kafr el Sheik (druga umowa). Efektem pierwszego porozumienia ma być budowa 1,2 tys. szkół $\mathrm{w}$ regionach $\mathrm{z}$ najniższym odsetkiem uczących się dzieci i objęcie nauczeniem około 100 tys. dzieci. Drugie porozumienie pozwoli na sfinansowanie budowy oczyszczalni ścieków i systemu wodociagowego w przedmiotowym regionie.

${ }^{11}$ Law No. 107 Regulating the Right to Public Gatherings, Processions and Peaceful Protests of November 24, 2013. 


\section{Konkluzje}

Próby oceny efektów nowego podejścia do idei promowania demokracji, rządów prawa i praw człowieka we współpracy z władzami Egiptu, dokonała sama Unia Europejska. 27 marca 2014 r. Komisja Europejska opublikowała komunikat Polityka sqsiedztwa na rozdrożu oraz towarzyszący raport na temat realizacji założeń Europejskiej Polityki Sqsiedztwa w odniesieniu do państw położonych w południowej części Morza Śódziemnego. Pełen ogólników raport wskazuje na złożoność sytuacji w regionie, podkreślając że stanowi ona wyzwanie, a cechuje ją znacząca polaryzacja społeczna i religijna (Implementation, 2014, s. 3). W komunikacie KE podkreśliła, że współpracę z Egiptem charakteryzuje ograniczony postęp oraz przekładanie w czasie negocjacji na temat planu działania i realizacji założeń partnerstwa. Polityczna sytuacja w tym państwie powoduje, że nie wcielono w życie rekomendacji dotyczących pogłębiania demokracji, sformułowanych w latach ubiegłych. Chodzi w szczególności o brak gwarancji niezależności systemu sądownictwa, liczne przypadki ograniczenia wolności zgromadzeń i stowarzyszania się, zabicie ponad 1300 osób przez egipskie służby bezpieczeństwa, naruszanie praw mniejszości, orzekanie (Wspólny, 2014, s. 7) i wykonywanie kary śmierci z powodów politycznych. Podobnie w tonie brzmi wcześniejsza rezolucja Parlamentu Europejskiego - z 23 października 2013 r. - w której wyrażono ubolewanie „Z powodu faktu, że postępy poczynione przez kraje partnerskie nie zawsze odpowiadają celom ustalonym wspólnie z UE [...]” postulujacc o „konsekwentne wdrażanie opartego na zachętach i zróżnicowanego podejścia "więcej za więcej' " (Rezolucja, 2013, par. 4).

„Europejska Polityka Sqsiedztwa jest polityką nieustannego zaangażowania” (Wspól$n y, 2014$, s. 17). Niestety zaangażowanie UE w promowanie demokracji, rządów prawa i praw człowieka w Egipcie po 2011 r. nie należy do udanych. Pomimo prób stworzenia skutecznych mechanizmów oddziaływania Unii na Egipt i pozostałe państwa Afryki północnej, nadal widoczna jest aktywność w myśl zasady „lepiej być obecnym niż nie być obecnym wcale”. Ceną za obecność ekonomiczna, za współpracę na rzecz walki $\mathrm{z}$ terroryzmem czy z nielegalną migracją, są unijne odstępstwa od rygorystycznego optowania za wcielaniem w tych państwach idei demokratycznych. W konsekwencji, przejawem skutecznego zaangażowania Unii Europejskiej w szerzenie demokracji i praw człowieka w państwach Afryki północnej jest współpraca z organizacjami pozarządowymi. Uznając, że budowanie demokracji nie może być pozostawione w rękach władz, lecz jest efektem zaangażowania społecznego, kluczowe znaczenie przypisano działalności takich organizacji. Organizacje funkcjonujące w państwach Afryki północnej nadal mają jednak utrudnioną działalność, są monitorowane przez aparaty władzy i partie rządzące (Cassarino, 2012, s. 10). Z tego względu, Unia Europejska stawia przed sobą zadanie wspierania takich organizacji przy wykorzystaniu nieformalnych kanałów wsparcia, również finansowego, skierowanego na realizację oddolnych inicjatyw pogłębiających demokrację. Realizacja tych założeń następuje między innymi w oparciu o European Endowment for Democracy - inicjatywę będącą najbardziej wymiernym efektem polskiej prezydencji w odniesieniu do wydarzeń Arabskiej wiosny.

Pytaniem otwartym pozostaje w jaki sposób kształtowana będzie aktywność Unii Europejskiej na rzecz promowania demokracji i praw człowieka w Egipcie i innych 
państwach Afryki północnej pod rządami nowej Wysokiej Przedstawiciel ds. Wspólnej Polityki Zagranicznej i Bezpieczeństwa - Federici Mogherini. Z jednej strony, Przedstawiciel pochodząca z Włoch - państwa, które szczególnie odczuło wydarzenia okresu Arabskiej wiosny - będzie prawdopodobnie dążyła do zacieśnienia współpracy z państwami regionu, za warunek kluczowy uznając demokratyzację i prawa człowieka. $Z$ drugiej jednak, zobowiązana będzie do realizowania stanowiska wypracowanego przez 28 państw członkowskich, z których część nadal będzie kierowała się głównie interesami partykularnymi. Paradoksalnie, kryzys migracyjny 2015 roku wymusił wspólną reakcję państw członkowskich na to zagrożenie. Uzgodniono, że sposobem rozwiązania problemu jest wsparcie finansowe dla państw trzecich, z których migranci pochodzą lub przez które przejeżdżają w drodze do UE. W konsekwencji, wizytę F. Mogherini w Egipcie w listopadzie 2015 r. poświęcono rozmowom na temat kwestii bezpieczeństwa regionalnego $\mathrm{w}$ związku z zagrożeniem terrorystycznym i kryzysem migracyjnym. Jednocześnie, wizyta była próbą odnowienia zaangażowania UE na rzecz promocji i ochrony praw człowieka i wartości demokratycznych. Wysoka Przedstawiciel spotkała się z przedstawicielami organizacji pozarządowych, podkreślając stałe zaangażowanie UE na rzecz praw człowieka. Podobnie, podczas spotkania ministerialnego Unii dla Śódziemnomorza z udziałem 43 państw, w tym Egiptu, wezwano do jedności w obliczu wspólnych wyzwań i zagrożeń, deklarując wolę zintensyfikowania kooperacji na rzecz stabilizacji w państwach Afryki północnej. Czas pokaże czy deklaracje przełożone zostaną na rzeczywiste działania.

\section{Bibliografia}

Archick K., Mix D. E. (2013), The United States and Europe: Responding to Change in the Middle East and North Africa, CRS Report for Congress, R 43105.

Balfour R. (2012), EU Conditionality after the Arab Spring, „European Institute of the Mediterranean Papers", nr 16.

Cassarino J. P. (2012), Reversing the Hierarchy of Priorities in EU-Mediterranean Relations, w: The European Union and the Arab Spring. Promoting Democracy and Human Rights in the Middle East, red. J. Peters, Lexington Books, Lanham-Boulder-New York-Toronto-Plymouth.

Cassarino J. P., Tocci N. (2012), The EU's Mediterranean policies after the Arab revolts: from crisis to a new order?, w: Regions and Crises: Challenges for Contemporary Regionalisms, red.

L. Fioramonti, Palgrave, Basingstoke.

Council Regulation (EC) No. $1257 / 96$ of 20 June 1996 concerning humanitarian aid (1996a), Official Journal L 163, vol. 39.

Council Regulation (EC) No. 976/1999 of 29 April 1999 laying down the requirements for implementation of Community operations other than those of development cooperation, which, within the framework of Community cooperation policy, contribute to the general objective of developing and consolidating democracy and the rule of law and to that of respecting human rights and fundamental freedoms in third countries (1999), Official Journal EC L 120, vol. 42

Council Regulation (EC) No. 1488/96 of 23 July 1996 on financial and technical measures to accompany (MEDA) the reform of economic and social structures in the framework of the Euro-Mediterranean Partnership (1996b), Official Journal L 189, vol. 39. 
Declaration on democracy, Session of the European Council. Conclusions, Copenhagen 7-8 April 1978 (1978), „Bulletin of the European Communities”, nr 3.

Eeckhout P. (2011), EU External Relations Law, Oxford University Press, Oxford-New York.

Egypt. Human Rights in Criris: Systematic Violations and Impunity (2014), Amnesty International. London.

Egypt: Roadmap to Repression. No End in Sight to Human Rights Violations (2014), Amnesty International, Peter Benenson House, London.

Emerson M., Noutcheva G., Popescu N. (2007), European Neighbourhood Policy Two Years On: Time Indeed for an 'ENP Plus', „CEPS Policy Brief', nr 126.

EU-Egypt relations. European Commission Memo (2013), http://www.europa.eu/rapid/press-release MEMO-13-751_en.htm, 22.03.2015.

EU-Egypt Task Force-Co-chairs conclusions (2012), http://www.conciluim.europa.eu, 20.08.2014.

Euro-Medditerranean Agreement establishing an Association between the European Communities and their Member States, of the one Part, and the Arab Republic of Egypt, of the other Part, Luxembourg, 25 of June 2001 (2004), Official Journal L 304, vol. 47.

Fioramonti L. (2012), Promoting Human Rights and Democracy. A New Paradigm for the European Union, w: The European Union and the Arab Spring. Promoting Democracy and Human Rights in the Middle East, red. J. Peters, Lexington Books, Lanham-Boulder-New York-Toronto-Plymouth.

Implementation of the European Neighbourhood Policy in 2013 Regional Report: A Partnership for Democracy and Shared Prosperity with the Southern Mediterranean Partners. Joint Staff Working Document (2014), SWD (2014) 100 final, Bruseels, 27.03.2014.

Joint Communication to the European Council, the European Parliament, the Council, the European Economic and Social Committee and the Committee of the Regions. A new response to a changing Neighbourhood (2011), COM(2011) 303 final, Brussels, 25.05.2011.

Judgment of the Court of Justice, Portugal v. Council, Case 268/94, 3.12.1996 (1996), Reports of Cases before the Court.

Kautsch K., Youngs R. (2009), The end of the 'Euro-Mediterranean vision', „International Affairs”, vol. 85 , nr 2 .

Malta Communiqué (2008), EU-League of Arab States Ministerial Meeting, 12 February. $\mathrm{http}: / /$ www.europarl.europa.eu, 20.08.2014.

Mangala J. (2013), Africa-EU Partnership on Democratic Governance and Human Rights, w: Africa and the European Union. A Strategic Partnership, red. J. Mangala, Palgrave Macmillan, New York.

Regulation (EC) No. 1638/2006 of the European Parliament and of the Council of 24 October 2006 laying down general provisions establishing a European Neighbourhood and Partnership (2006), Official Journal L 310, vol. 49.

Report from the Commission on the implementation of measures intended to promote observance of human rights and democratic principles (for 1995), COM(96) 672 final, Brussels. 17.01.1997.

Report from the Commission on the implementation of measures intended to promote observance of human rights and democratic principles in external relations for 1996-1999 (2000), $\operatorname{COM}(2000) 726$ final, Brussels.

Rezolucja Parlamentu Europejskiego z 23 października 2013 r. w sprawie Europejskiej Polityki Sasiedztwa: dazienie do wzmocnienia partnerstwa. Stanowisko Parlamentu Europejskiego w sprawie sprawozdań za rok 2012 (2013/2621(RSP)), P7_TA(2013)0446. 
Rozporządzenie Rady (UE) nr 270/2011 z 21 marca 2011 r. w sprawie środków ograniczajacych skierowanych przeciwko niektórym osobom, podmiotom i organom w zwiqzku z sytuacja w Egipcie (2011), Dziennik Urzędowy L 76, vol. 54.

Schmitter Ph. C., Brouwer I. (1999), Conceptualizing, Researching and Evaluating Democracy Promotion and Protection, EUI Working Paper SPS No. 99/9.

The European Union and the External Dimension of Human Rights Policy: From Rome to Maastricht and Beyond (1995), Communication from the Commission to the Council and the European Parliament, COM(1995) 567 final, Brussels.

The European's Union Role in promoting human rights and democratisation in third countries (2001), Communication from the Commission to the Council and the European Parliament, $\operatorname{COM}(2001) 252$ final, Brussels.

The Nobel Peace Prize for 2012 Announcement (2012), The Norwegian Nobel Committee, Oslo, http:www.nobelpeaceprize.org (24.09.2013).

Traktat ustanawiający Wspólnotę Europejska, Maastricht (1992), Dziennik Urzędowy EC C 224, vol. 35.

Traktat ustanawiajacy Wspólnotę Europejska, Nicea (2001), Dziennik Urzędowy C 80, 10.03.2001.

Traktat o Unii Europejskiej, Lizbona (2007), Dziennik Urzędowy 2012, C 326.

Traktat o Unii Europejskiej, Maastricht (1992), Dziennik Urzędowy WE C 191, vol. 35.

Traktat o funkcjonowaniu Unii Europejskiej, Lizbona (2007), Dziennik Urzędowy 2012, C 326.

Traktat z Amsterdamu zmieniajacy Traktat o Unii Europejskiej, Traktaty ustanawiajace Wspólnoty Europejskie i niektóre zwiqzane z nimi akty, Amsterdam (1997), Dziennik Urzędowy WE C 340, vol. 40 .

Wieruszewski R. (2008), Rola i znaczenie Karty Praw Podstawowych Unii Europejskiej dla ochrony praw czlowieka, „Przegląd Sejmowy”, nr 2.

Wspólne oświadczenie Rady i przedstawicieli rzadów państw czlonkowskich zebranych w ramach Rady, Parlamentu Europejskiego i Komisji w sprawie polityki rozwojowej Unii Europejskiej: „Konsensus Europejski” 2006/C 46/01 (2006), Dziennik Urzędowy C 46, vol. 49, 24.2.2006.

Wspólny komunikat do Rady Europejskiej, Parlamentu Europejskiego, Rady Europejskiego Komitetu Ekonomiczno-Spotecznego oraz Komitetu Regionów z 8 marca 2011 r. - Partnerstwo na rzecz demokracji i wspólnego dobrobytu z poludniowym regionem Morza Sródziemnego (2011), $\operatorname{COM}(2011) 200$ wersja ostateczna, Bruksela, 8.03.2011.

Wspólny komunikat do Rady Europejskiej, Parlamentu Europejskiego, Rady Europejskiego Komitetu Ekonomiczno-Spolecznego oraz Komitetu Regionów. Polityka sąsiedztwa na rozdrożu: Realizacja Europejskiej Polityki Sasiedztwa w 2013 r: (2014), JOIN(2014) 12 wersja ostateczna. Bruksela, 27.03.2014.

Yilmaz H. (2009), The International Context, w: Democratization, red. Ch. W. Haerpfer, P. Bernhagen, R. F. Inglehart, Ch. Welzel, Oxford University Press, Oxford.

\section{Streszczenie}

Zmiany zapoczątkowane Rewolucja 25 stycznia nie zagwarantowały oczekiwanej demokratyzacji. $Z$ tego względu, celem Unii Europejskiej i państw członkowskich stało się wzmocnienie stabilności w państwie, promocja wartości demokratycznych i praw człowieka. Celem niniejszego opracowania jest analiza działań skierowanych na wsparcie procesu demokratyzacji w Egipcie, podejmowanych przez Unię Europejską, a także ocena dotychczasowej aktywności i wskazanie przyczyn jej nieskuteczności.

Slowa klucze: demokracja, rządy prawa, prawa człowieka, Unia Europejska, Egipt 


\section{Democracy, rule of law and respect for human rights in the European Union's activities towards Egypt}

\section{Summary}

Contrary to expectations, the changes initiated by the '25 January Revolution' have not strengthened democratic principles in Egypt. Therefore, the European Union and its member states have sought to support the stability of this state, promote democratic values and human rights. The purpose of this study is to analyse EU activities aimed at fostering the democratisation process in Egypt, as well as to assess these activities so far and identify the reasons for their ineffectiveness.

Key words: democracy, rule of law, human rights, European Union, Egypt 